\title{
Thiamine pyrophosphate riboswitch regulation: a new possible mechanism involved in the action of nalidixic acid
}

\section{[Tiamin pirofosfat riboswitch düzenlemesi: nalidiksik asitin etkisine karışan yeni bir olası mekanizma]}

https://doi.org/10.1515/tjb-2020-0168

Received April 5, 2020; accepted July 15, 2020;

published online November 12, 2020

\section{Abstract}

Objectives: The development of novel antibiotic compounds requires riboswitches; in fact, riboswitches are RNA elements present in the $5^{\prime}$ untranslated region of bacterial mRNA and have a metabolite-binding aptamer domain and an expression platform regulating the expression of vital genes. In the present research, one riboswitch, namely thi-box riboswitch with distinct regulatory mechanisms, was studied. It recognizes Thiamine Pyrophosphates (TPP) regulating TPP-biosynthesis genes in Escherichia coli.

Methods: First, the compounds similar to riboswitch ligands were studied, and their binding with the riboswitch and nucleosides was investigated by molecular docking. Then, compounds containing high binding energy were chosen, and their minimum inhibitory concentration in E. coli was determined by the MIC test. Finally, the binding

\footnotetext{
*Corresponding author: Soroush Sardari, Drug Design and Bioinformatics Unit, Medical Biotechnology Department, Biotechnology Research Center, Pasteur Institute of Iran, Tehran, Iran, E-mail: ssardari@hotmail.com. https://orcid.org/0000-0003-20807402

Sahar Shahidi, Seyed Sadegh Shahraeini and Yekta Farmahini Farahani, Drug Design and Bioinformatics Unit, Medical Biotechnology Department, Biotechnology Research Center, Pasteur Institute of Iran, Tehran, Iran. https://orcid.org/0000-0002-4854570X (S.S. Shahraeini)
}

of compounds to nucleotides and RNA was investigated by measuring the absorbance spectrum through NanoDrop and circular dichroism (CD).

Results: In the thi-box riboswitch, nalidixic acid was found to have the best binding energy $(-5.31 \mathrm{~kJ} / \mathrm{mol})$, and it inhibited $E$. coli growth at the minimum inhibitory concentration of $125 \mu \mathrm{g} / \mathrm{mL}$, and it could bind to ribonucleosides and RNA in vitro.

Conclusions: One possible mechanism involved in the action of nalidixic acid in inhibiting the $E$. coli growth is to influence thi-box riboswitch.

Keywords: antibacterial agents; circular dichroism; molecular docking; riboswitch; RNA aptamers; spectrophotometry.

\section{Özet}

Amaç: Yeni antibiyotik bileşiklerinin geliştirilmesi için riboswitchler gerekir; gerçekte, riboswitchler bakteriyel mRNA'nın 5 'tercüme edilmemiş bölgesinde bulunan RNA elementleridir ve bir metabolit bağlayıcı aptamer alanına ve hayati genlerin ekspresyonunu düzenleyen bir ekspresyon platformuna sahiptir. Mevcut araştırmada, farklı düzenleyici mekanizmalara sahip bir riboswitch, yani thi-box riboswitch incelenmiştir. Escherichia coli'de TPP-biyosentez genlerini düzenleyen Tiamin Pirofosfatları (TPP) tanır.

Gereç ve Yöntem: İlk olarak, riboswitch ligandlarına benzer bileşikler incelendi ve riboswitch ve nükleosidlerle bağlanma moleküler yerleştirme ile araştırıldı. Daha sonra, yüksek bağlanma enerjisi içeren bileşikler seçildi ve E. coli'deki minimum önleyici konsantrasyonları MIC testi 
ile belirlendi. Son olarak, bileşiklerin nükleotitlere ve RNA'ya bağlanması, absorbans spektrumunun NanoDrop ve Dairesel Dikroizm (CD) yoluyla ölçülmesiyle araştırıldı. Bulgular: $\mathrm{Bu}$ thi-box riboswitchinde, nalidiksik asidin $-5.31 \mathrm{~kJ} / \mathrm{mol}$ 'lük en yüksek bağlanma enerjisine sahip olduğu bulundu ve minimum $125 \mathrm{ug} / \mathrm{mL}$ inhibitör konsantrasyonunda $E$. coli büyümesini inhibe etti ve ribonükleosidlere ve RNA'ya bağlanabilir. laboratuvar ortamında.

Sonuç: Nalidiksik asidin $E$. coli büyümesini inhibe etme etkisine dahil olan bir mekanizma, thi-box riboswitchini etkilemektir.

Anahtar Kelimeler: Antibakteriyel ajanlar; Dairesel dikroizm; Moleküler doking; Riboswitch; RNA aptamerleri; Spektrofotometri.

\section{Introduction}

In the past decade, the problem of multiple drug resistance (MDR) has increased relatively due to the extreme use of antibiotics. In addition, MDR is caused as a result of drug design, mostly relying on the restricted chemical frameworks providing the opportunity for pathogens to hook up the action mechanisms of antibiotics [1]. Thus, it is necessary to discover new antibacterial targets.

RNA is one of the targets on which some classes of antibiotics act, like rRNA and tRNA, which have been targeted by a large number of antibiotics. Riboswitches could be the next generation of RNA-based targets. As RNA elements, they form and regulate receptors for individual small molecules and gene expression in response to ligand binding, respectively [2]. Riboswitches have two structural domains, one of which is an aptamer domain binding to a specific metabolite. Another domain is responsible for regulating gene expression. When a ligand binds to an aptamer domain, expression platform can bring about either transcription termination by formation a terminator hairpin or translation inhibition by sequestering the ribosome binding site [3].

Riboswitch-adjusted genes are involved in abundant routes of bacterial biosynthesis; more than $2 \%$ of the genes are riboswitch-regulated [4]. Studies showed that riboswitches are responsible for the expression of necessary genes for survival or virulence in some bacterial pathogens. It is argued that targeting riboswitches controlling virulence genes may bring about a positive therapeutic effect. Moreover, predicting a synthetic metabolite mimic to target a riboswitch managing necessary genes for survival might bring about deadly results if the natural metabolite is not imitated [5].
Thiamine pyrophosphate-sensing riboswitch or thibox RNA is one of the earliest discovered riboswitches. More than 1000 thi-box sequences have been discovered in 87 organisms [6]. This riboswitch system is found in several phyla, including all types of gram-positive bacteria [7]. Like other riboswitches, thi-box attaches to its cognate metabolite with strong affinity and specificity [8]. Some thi-box RNAs are able to bind to TPP with dissociation constants as small as $20 \mathrm{nM}$ [9] Thi-box riboswitch binding to thiamine pyrophosphate (TPP) regulates genes that encode protein products involved in biosynthesis and transport of thiamine. It regulates a wide range of genes, including aminoacyl-tRNA synthetase genes and genes that contributed to amino acid biosynthesis and transport [10]. Pyrithiamine Pyrophosphate (PTPP) has also been shown to interact with thi-box riboswitches, resulting in the downregulation of thiamine production. It could be said that riboswitches are targeted by the structure-orientated design of antibacterial reagents [11].

Riboswitches are capable of interacting with low molecular weight ligands in some binding pocket with strong affinity and specificity. This issue provides the researchers with the opportunity to design compounds selectively targeting riboswitches. Due to the difficult identification of ligands, the best probable method to detect riboswitch modulators is screening the small molecule libraries containing ligand analogs $[12,13]$. In this paper, the effect of the drugs similar to TPP riboswitch inhibitor compounds in E. coli was investigated. After finding similar compounds, their binding interaction with the TPP riboswitch was evaluated using in silico and in vitro methods to investigate their antimicrobial effects.

\section{Material and methods}

\section{Materials}

Nutrient agar, nutrient broth medium, $\mathrm{NaCl}$, and dimethyl sulfoxide were obtained from Merck (Darmstadt, Germany), and streptomycin was supplied from Sigma (Taufkirchen, Germany). Deionized water was used for solutions. The thi-box riboswitch active site, with the sequence of $5^{\prime}$ GUGCCCUUCUGCGUGAAGGCUGAGAA 3', was purchased from Eurofins Genomics (Ebersberg, Germany).

\section{Similarity search}

Previously investigated compounds similar to TPP with riboswitch inhibiting activity against thi-box of $E$. coli were reviewed through the related literature. Then, a similarity search was performed on all drugs listed in the Drug Bank by Chemoffice program (Version 8.0, 2004 Cambridge Soft). Compounds with $80-90 \%$ similarity available at 
Table 1: The results of molecular docking in thi-box riboswitch. ${ }^{a}$

\begin{tabular}{lllr}
\hline Riboswitch & $\begin{array}{l}\text { Inhibitor } \\
\text { ligands }\end{array}$ & Ligands & $\begin{array}{r}\text { Binding } \\
\text { energy, } \\
\text { kJ/mol }\end{array}$ \\
\hline Thi-box & Pyrithiamine & Pyrithiamine & -3.69 \\
riboswitch & & Pyridoxamine & -2.95 \\
& & Thiamine & -3.86 \\
& Thiamine phosphate & -1.89 \\
& & Pyrithiamine & -6.88 \\
& pyrophosphate & \\
& Benfothiamine & Benfothiamine & -5.19 \\
& & 4-Hydroxybenzoic acid & -3.69 \\
& & Ferulic acid & -4.21 \\
& & Aminopterin & -4.36 \\
& Nalidixic acid & -5.31 \\
\hline
\end{tabular}

${ }^{\mathrm{a}}$ The inhibitor ligands and the ligands obtained from the related literature and the similarity search was done with ChemOffice.

databases of www.Drugbank.ca and www.pubchem.ncbi.nlm.nih.gov were searched. The final list of candidate compounds was made from the results of similarity search, including ligands and their similar compounds (Table 1).

\section{Molecular docking analysis}

For molecular docking study, the crystal structure of the TPP riboswitch was obtained from the Protein Data Bank (PDB ID 2HOJ). Molecular docking study was performed using AutoDock 1.5.6 suite, consisting of automated docking tools that use Lamarckian genetic algorithm [14]. Hydrogen atoms were added using WLViewerLite40, 2007. The positions of the hydrogen atoms were minimized using the MarvinSketch 6.2.2 force field [15]. All the compounds used for docking analysis were constructed by ChemDraw ultra ver.12 as mol file, and then their energies were minimized. In the docking process of thi-box riboswitch with nalidixic acid or benfothiamine, the grid points were fixed at a resolution of $375 \AA$, with the grid dimensions as $40 \times 40 \times 40 \AA$. In the docking performed between ribonucleosides and the compounds, the grid points were fixed at a resolution of $0.608 \AA$, with the grid dimensions as $20 \times 20 \times 20 \AA$ [16].

\section{Antimicrobial activity measurement}

For antibacterial activity assay, Escherichia coli ATCC K12 was used as the test strain. Antibiotics and test compounds were dissolved in Dimethyl Sulfoxide (DMSO) to prepare a concentration of $10 \mathrm{mg} / \mathrm{mL}$. To specify antibacterial activity, broth microdilution was performed as a standard method [17]. Streptomycin and DMSO were used as positive and negative control, respectively. E. coli was cultured on nutrient agar medium for $24 \mathrm{~h}$ at $37{ }^{\circ} \mathrm{C}$. The bacteria were collected and resuspended in $\mathrm{NaCl}(0.9 \%)$. The suspension was adjusted to an OD of 0.132 at $600 \mathrm{~nm}$ wavelength. Then, the bacterial suspension was diluted 100 times with nutrient broth medium [17]. The 96-well plates were incubated at $37^{\circ} \mathrm{C}$ for $24 \mathrm{~h}$, and the OD values of the wells were recorded every $2 \mathrm{~h}$. Wells with no signs of bacterial growth were marked as MIC values. The tests were conducted in duplicates.

\section{UV-visible and circular dichroism spectroscopy measurement}

Spectroscopy was used for in vitro study of the interaction between compounds and RNA. First of all, the materials, including nalidixic acid, benfothiamine, and nucleosides, were dissolved in $\mathrm{H}_{2} \mathrm{O}$. The concentration of these compounds was equal to $50 \mu \mathrm{g} / \mathrm{mL}$. The RNA was dissolved in $\mathrm{H}_{2} \mathrm{O}$, and the concentration was $0.133 \mathrm{mM}$. For NanoDrop measurements (Thermo Scientific, USA), the solvent was used as blank, and then UV absorbance of thi-box riboswitch active site and nucleosides was measured in the absence and presence of the test compounds. Spectra were recorded in the range of $200-800 \mathrm{~nm}$. In circular dichroism spectroscopy, the concentration of substances was similar to the previous method. All the compounds were dissolved in $\mathrm{H}_{2} \mathrm{O}$ and were scanned in the range of $190-350 \mathrm{~nm}$ at a speed of $200 \mathrm{~nm} / \mathrm{min}$. A quartz cell of $1 \mathrm{~cm}$ path length was used at $25^{\circ} \mathrm{C}$ for The spectropolarimeter (JASCO J-810C, Tokyo, Japan), continuously flushed with nitrogen [18].

\section{Results and discussion}

\section{Inhibitor ligands of thi-box riboswitch}

For identifying new riboswitch modulating entities, E. coli riboswitch targeting compounds were investigated by in silico screening. Moreover, artificial compounds were designed rationally, and groups of naturally occurring prospective riboswitch activators were investigated. The results of previous studies showed that benfothiamine and pyrithiamine were effective on thi-box riboswitch in $E$. coli [19], so in this study, these compounds were selected to be used in cheminformatics strategy. The compounds with $80-90 \%$ similarity to the inhibitor ligands of thi-box riboswitch were found via similarity search (Table 1).

The compounds with the highest similarity to benfothiamine were 4-hydroxybenzoic acid, ferulic acid, aminopterin, and nalidixic acid. The agents with the highest similarity to pyrithiamine were pyridoxamine, thiamine, thiamine phosphate, and pyrithiamine pyrophosphate. The compounds were evaluated with Lipinski's rule of five, and the binding energy of these combinations was studied.

\section{Docking}

None of the similar compounds of pyrithiamine showed suitable binding energy values towards the thi-box riboswitch except for pyrithiamine pyrophosphate. This compound is unstable due to its phosphate groups; hence in this study, similar ligands to benfothiamine were studied. The results of molecular docking showed 
A

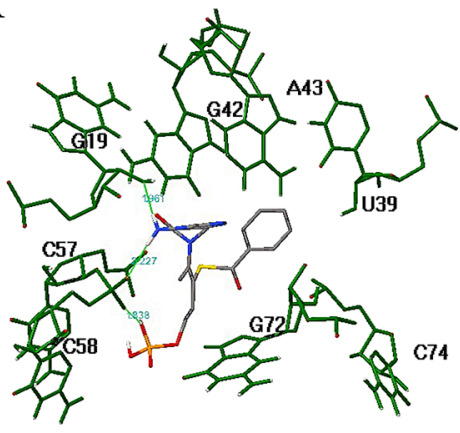

B

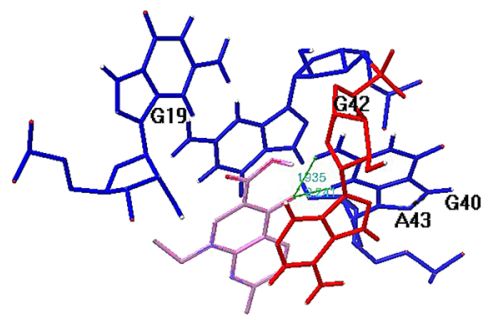

Figure 1: Interaction of benfothiamine and nalidixic acid with thi-box riboswitch. A: Benfothiamine has hydrogen bonds with $\mathrm{G} 19, \mathrm{C} 57$, and $\mathrm{C} 58$ of the active site in thibox riboswitch. B: Nalidixic acid has hydrogen bonds with $\mathrm{A} 43$ of the active site in thi-box riboswitch. that nalidixic acid had the lowest binding energy $(-5.31 \mathrm{~kJ} / \mathrm{mol})$ among the similar compounds of benfothiamine whose binding energies ranged from -3.69 to $-5.31 \mathrm{~kJ} / \mathrm{mol}$ (Table 1 ), which means that nalidixic acid interacts with the TPP ligand binding site more strongly than other compounds. The molecular docking of benfothiamine and nalidixic acid with nucleosides are shown in supplementary data (Table 1S). According to the results of binding energies, the interaction of nalidixic acid with the four nucleosides, namely adenosine, guanosine, cytidine, and uridine, was much stronger than that of benfothiamine, indicating that nalidixic acid is able to form stronger hydrogen bonds with nucleosides than benfothiamine. Carbonyl group of nalidixic acid forms hydrogen bonds with the hydroxymethyl group of the sugar ring of the four nucleosides. Moreover, the binding energies of nalidixic acid and benfothiamine with the TPP riboswitch of $E$. coli were much lower than their binding energies with the nucleosides, showing that the compounds have better interaction with the specific 3D structure of nucleosides existing in the TPP riboswitch.

Hydrogen bond, van der Waals, and electrostatic interactions stabilized the interaction of the ligands with active site bases. While carbonyl oxygen atom of nalidixic acid was interacting with the A43 base by two hydrogen bonds, benfothiamine, as a positive control with $-5.19 \mathrm{~kJ} /$ mol of binding energy, was interacting with bases of G19, C57, and $\mathrm{C} 58$ by hydrogen bonds (Figure 1A). Benfothiamine was reported to be less than half as active as TPP [8]. The decrease in the affinity of benfothiamine towards TPP riboswitch could be the result of disrupted thiazole ring, which increases its flexibility and does not allow it to adopt the requisite conformation [19].

TPP riboswitch in E.Coli consists of two parallel helical arms, and thiamine pyrophosphate, as a cognate ligand of the riboswitch, is positioned between them perpendicularly [20]. Negatively charged phosphate groups of TPP with the coordination of $\mathrm{Mg}^{2+}$ ions were also found to have a crucial role in interaction with the TPP riboswitch $[8,21]$.
The carboxylic acid group of nalidixic acid may imitate the role of pyrophosphate in TPP and enable it to reach into the pyrophosphate-binding pocket, stabilizing the interaction with the riboswitch. TPP ligand binding site in thi-box riboswitches is between nucleotides of G19, G42, and A43 stabilized by hydrogen bonds or stacking. TPP stacks between $\mathrm{G} 42$ and A43 bases. The aminopyrimidine ring of TPP forms a hydrogen bond to G40 in the pyrimidine sensor helix, and its pyrophosphate interacts with the pyrophosphate sensor helix of riboswitch [19].

\section{Antibacterial activity}

Growth inhibition experiments were performed using various concentrations of nalidixic acid, benfothiamine, along with streptomycin as positive controls, and DMSO as a negative control. The results are shown in supplementary data (Table $2 \mathrm{~S}$ ). The MIC values were in the range of $15.625-1000 \mu \mathrm{g} / \mathrm{mL}$. The minimum inhibitory concentration of nalidixic acid was equal to $125 \mu \mathrm{g} / \mathrm{mL}$, which is one eighth more than that of benfothiamine, showing that the antibacterial activity of nalidixic acid is within the range. Benfothiamine showed poor inhibition activity against $E$. coli with the MIC of $1000 \mu \mathrm{g} / \mathrm{mL}$, the same as DMSO. Lacking the thiazole ring, benfothiamine cannot induce efficient structural rearrangements in the riboswitch [8]. So, it appears that benfothiamine is not an effective antibacterial agent against $E$. coli. The MIC did not improve after adding benfothiamine to nalidixic acid, suggesting that these compounds do not have a synergistic effect and probably have the same mechanism of action.

In a study, by in silico compound screening followed by validation in bacterial cultures, some small molecules which were structurally similar to benfothiamine and nalidixic acid were discovered with riboswitch inhibition antibacterial activity [22]. They showed MICs in the range of $32-512 \mu \mathrm{g} / \mathrm{mL}$. 
A

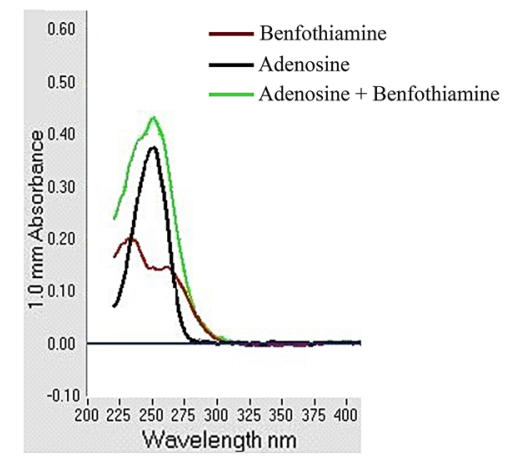

C

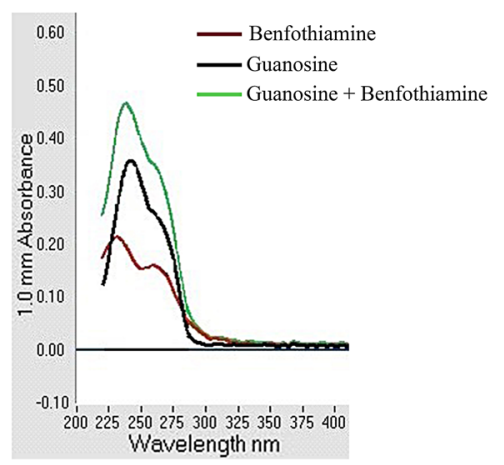

B

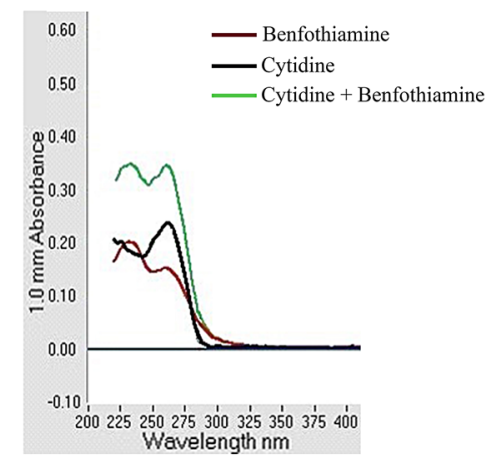

D

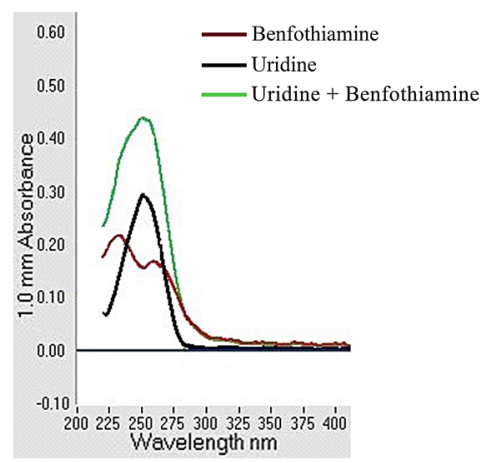

Figure 2: The UV absorbance of benfothiamine, nucleosides, and their mixture. Benfothiamine slightly shifted the spectra of A: adenosine, B: cytidine, C: guanosine, and $D$ : uridine.
A

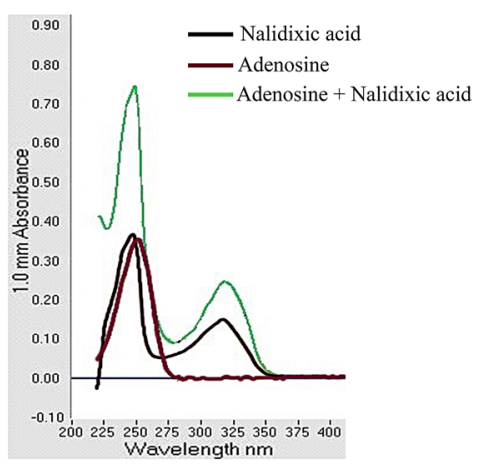

C

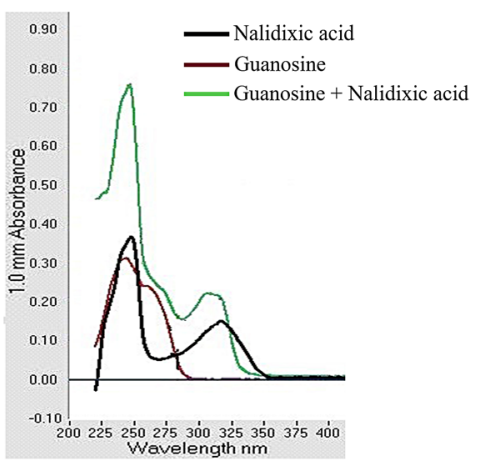

B

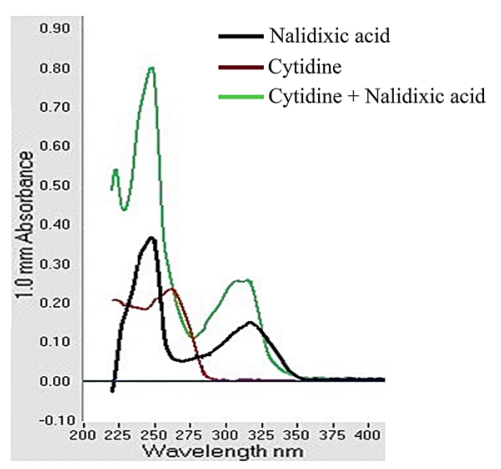

D

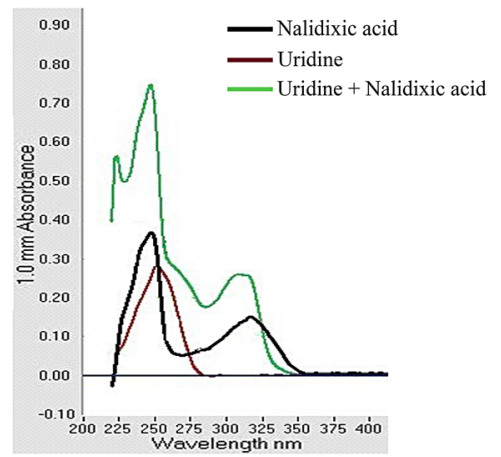

Figure 3: The UV absorbance of nalidixic acid, nucleosides, and their mixture. Nalidixic acid slightly shifted the spectra of A: adenosine, B: cytidine, C: guanosine, and $\mathrm{D}$ : uridine. 


\section{UV-visible absorption spectroscopy}

For ensuring the interaction mode, UV absorption spectroscopy was conducted. The docking results showed that the tested compounds interacted with the bases of the active site in the riboswitch. In this study, NanoDrop was used to monitor the changes in absorption properties. First, the interaction of bases with compounds was tested, and then the interaction between RNA and compounds was measured.

The results of UV absorbance of nucleosides are shown in supplementary data (Table 3S). The absorption peak of adenosine was observed at $250 \mathrm{~nm}$. When it was mixed with benfothiamine, the peak shifted to $254 \mathrm{~nm}$. Mixing nalidixic acid with adenosine resulted in a $3 \mathrm{~nm}$ shift. Neither nalidixic acid nor benfothiamine changed the wavelength of maximum absorbance of guanosine more than $3 \mathrm{~nm}$. Regarding cytidine, while benfothiamine resulted in a $3 \mathrm{~nm}$ shift in cytidine peak, a $5 \mathrm{~nm}$ shift was observed in its maximum absorbance from 251 to $256 \mathrm{~nm}$ in the presence of nalidixic acid. The maximum absorbance of uridine appeared at the wavelength of $252 \mathrm{~nm}$, shifted to

A
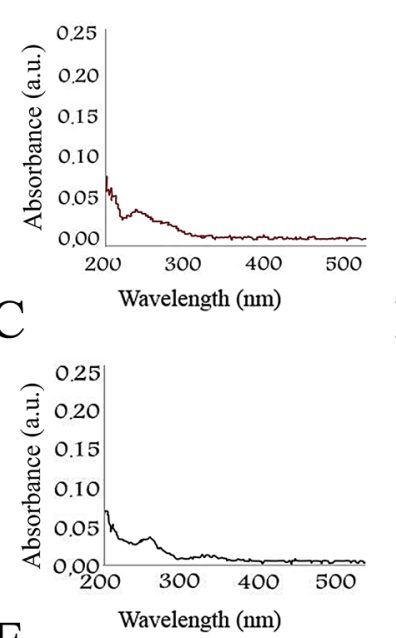

$\mathrm{E}$

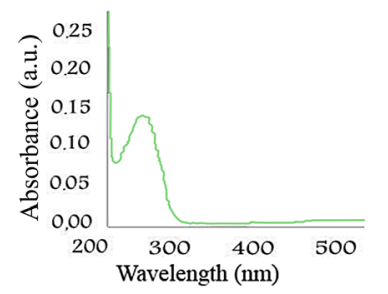

Figure 4: Absorption spectra of A: benfothiamine, $B$ : benfothiamine mixed with RNA, C: nalidixic acid, D: nalidixic acid mixed with RNA, and $\mathrm{E}$ : RNA.
$250 \mathrm{~nm}$ as mixed with benfothiamine. By adding nalidixic acid to uridine, the maximum absorbance of the nucleoside underwent a shift of $6 \mathrm{~nm}$. Generally, both compounds slightly shifted the spectra of the nucleosides (Figures 2, 3), indicating weak interactions between them, as shown by the docking results. Furthermore, the minimum absorbance of nalidixic, observed at $268 \mathrm{~nm}$, clearly underwent a red shift as mixed with the nucleosides (Figure 3). While the magnitude of the shift after mixing with adenosine or cytidine was around $12 \mathrm{~nm}$, that of guanosine or uridine was more than $20 \mathrm{~nm}$. This confirms the results of the molecular docking of the compounds with the nucleosides, showing that docking energies of nalidixic acid were lower than those of benfothiamine.

The absorption spectrum of the TPP riboswitch sequence is shown in Figure 4E. When it was mixed with benfothiamine, no significant change was observed in its spectrum (Figure 4B). The UV absorption spectrum of RNA showed huge changes in the presence of nalidixic acid (Figure 4D) so that its maximum absorption peak shifted towards longer wavelengths. This bathochromic effect could be attributed to the fall in the energy gap between the highest and the lowest molecular orbitals (HUMO and LUMO) as a result of interactions [23]. The drastic change observed in the spectrum indicates that there was a strong interaction between RNA and nalidixic acid, as already shown in molecular docking. A comparison of the riboswitch's spectrum shift with that of riboswitch's spectra in the presence of nalidixic acid showed that it interacts with the specific sequence forming a particular structure.

\section{Circular dichroism spectroscopy}

For studying the conformational changes in the thi-box riboswitch, circular dichroism (CD) was used. As shown in Figure $5 \mathrm{~A}$, adding nalidixic acid to the RNA produced changes in CD spectrum of the riboswitch. There was a positive peak at 16.05 mdeg near $269 \mathrm{~nm}$ and a negative peak at -23.80 mdeg around $207 \mathrm{~nm}$ in the riboswitch spectrum, whereas a structure including nalidixic acid and the RNA reached its positive peak at 10.28 mdeg around $274 \mathrm{~nm}$ and its negative peak at -10.10 mdeg near $210 \mathrm{~nm}$. Hence, the intensities of both the negative and positive bands in the mixture's spectrum were decreased, which may be associated with the unwinding of the RNA due to its binding with nalidixic acid. Similarly, it has been reported that the peak intensity of TPP riboswitch decreased by titration against TPP [9]. These shifts indicated that the compound was bound to the RNA and changed its conformation; therefore, the interaction of nalidixic acid 
A

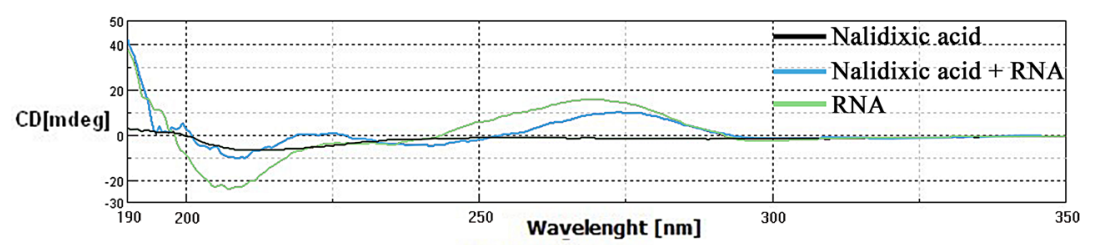

B

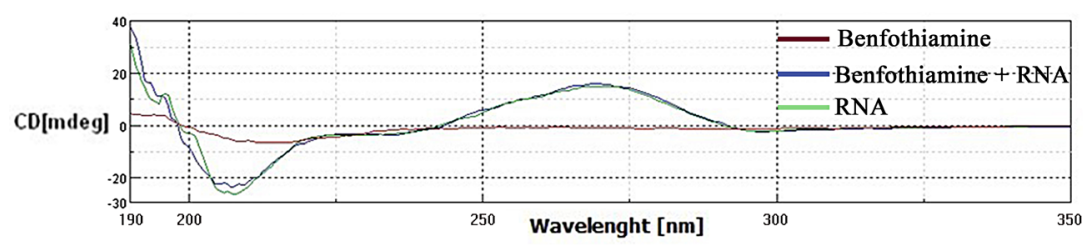

Figure 5: $A$ : The $C D$ spectrum of nalidixic acid, RNA, and mix of them. B: The CD spectrum of benfothiamine, RNA, and mix of them. Nalidixic acid binds to the RNA and changes its spectrum, but the spectrum of RNA is almost the same in the presence and absence of benfothiamine. with RNA was found to be significant. Adding benfothiamine had no effect on the riboswitch $C D$ spectrum (Figure 5B), so the interaction of benfothiamine with RNA was found to be weak [24].

In S-adenosylmethionine (SAM) II riboswitch, the addition of SAM, as the cognate ligand of the riboswitch, resulted in sizeable changes in the CD spectrum, including hypsochromic and hypochromic shifts, indicating changes in the folding of the RNA [25].

\section{Conclusion}

The present study was aimed to investigate the potential of TPP riboswitches as a target for an antibacterial agent. Among similar compounds of benfothiamine, as inhibitor ligand of the riboswitch, nalidixic acid was found to bind to the active site of the thi-box riboswitch from our docking study. The results of in vitro tests obtained by measuring the absorption spectra using circular dichroism and NanoDrop revealed details regarding the interaction between RNA sequences and nalidixic acid. It also effectively inhibited the growth of $E$. coli in the MIC test. Therefore, it can be concluded that nalidixic acid is able to inhibit $E$. coli growth by having an influence on thi-box riboswitch as one of the possible mechanisms of action.

Acknowledgments: We would like to thank the Drug Design and Bioinformatics Unit at Pasteur Institute of Iran for supporting this work.

Research funding: None declared.

Author contributions: All authors have accepted responsibility for the entire content of this manuscript and approved its submission.
Competing interests: The authors declare that there is no conflict of interests regarding the publication of this article. Ethical Approval: The conducted research is not related to either human or animal use.

\section{References}

1. Blount KF, Breaker RR. Riboswitches as antibacterial drug targets. Nat Biotechnol 2006;24:1558-64.

2. Brantl S. Bacterial gene regulation: from transcription attenuation to riboswitches and ribozymes. Trends Microbiol 2004;12:473-5.

3. Machtel P, Bakowska-Zywicka K, Zywicki M. Emerging applications of riboswitches - from antibacterial targets to molecular tools. J Appl Genet 2016;57:531-41.

4. Tucker BJ, Breaker RR. Riboswitches as versatile gene control elements. Curr Opin Struct Biol 2005;15:342-8.

5. Mehdizadeh Aghdam E, Hejazi MS, Barzegar A. Riboswitches: from living biosensors to novel targets of antibiotics. Gene 2016; 592:244-59.

6. Gutierrez-Preciado A, Henkin TM, Grundy FJ, Yanofsky C, Merino E. Biochemical features and functional implications of the RNA-based T-box regulatory mechanism. Microbiol Mol Biol Rev 2009;73:36-61.

7. Mironov AS, Gusarov I, Rafikov R, Lopez LE, Shatalin K, Kreneva RA, et al. Sensing small molecules by nascent RNA: a mechanism to control transcription in bacteria. Cell 2002;111:747-56.

8. Winkler W, Nahvi A, Breaker RR. Thiamine derivatives bind messenger RNAs directly to regulate bacterial gene expression. Nature 2002;419:952.

9. Yamauchi T, Miyoshi D, Kubodera T, Nishimura A, Nakai S, Sugimoto N. Roles of $\mathrm{Mg}^{2+}$ in TPP-dependent riboswitch. FEBS Lett 2005;579:2583-8.

10. Grundy FJ, Henkin TM. From ribosome to riboswitch: control of gene expression in bacteria by RNA structural rearrangements. Crit Rev Biochem Mol Biol 2006;41:329-38.

11. Sudarsan N, Cohen-Chalamish S, Nakamura S, Emilsson GM, Breaker RR. Thiamine pyrophosphate riboswitches are targets for the antimicrobial compound pyrithiamine. Chem Biol 2005;12: 1325-35. 
12. Rekand IH, Brenk R. Ligand design for riboswitches, an emerging target class for novel antibiotics. Future Med Chem 2017;9: 1649-63.

13. Perkins KR, Atilho RM, Moon MH, Breaker RR. Employing a ZTP riboswitch to detect bacterial folate biosynthesis inhibitors in a small molecule high-throughput screen. ACS Chem Biol 2019;14: 2841-50.

14. Morris GM, Goodsell DS, Halliday RS, Huey R, Hart WE, Belew RK, et al. Automated docking using a Lamarckian genetic algorithm and an empirical binding free energy function. J Comput Chem 1998;19:1639-62.

15. Gerber PR, Müller K. MAB, a generally applicable molecular force field for structure modelling in medicinal chemistry. J Comput Aided Mol Des 1995;9:251-68.

16. Scorzoni L, Benaducci T, Almeida AMF, Silva DHS, Bolzani VDS, Gianinni MJSM. The use of standard methodology for determination of antifungal activity of natural products against medical yeasts Candida sp and Cryptococcus sp. Braz J Microbiol 2007;38:391-7.

17. Cuenca-Estrella M, Lee-Yang W, Ciblak MA, Arthington-Skaggs BA, Mellado E, Warnock DW, et al. Comparative evaluation of NCCLS M27-A and EUCAST broth microdilution procedures for antifungal susceptibility testing of Candida species. Antimicrob Agents Chemother 2002;46: 3644-7.

18. Jiang Z, Vasil A, Vasil M, Hodges R. "Specificity determinants" improve therapeutic indices of two antimicrobial peptides piscidin 1 and dermaseptin S4 against the gram-negative pathogens Acinetobacter baumannii and Pseudomonas aeruginosa. Pharmaceutical 2014;7:366-91.

19. Edwards TE, Ferre-D'Amare AR. Crystal structures of the thi-box riboswitch bound to thiamine pyrophosphate analogs reveal adaptive RNA-small molecule recognition. Structure 2006;14: 1459-68.

20. Serganov A, Polonskaia A, Phan AT, Breaker RR, Patel DJ. Structural basis for gene regulation by a thiamine pyrophosphate-sensing riboswitch. Nature 2006;441:1167-71.

21. Winkler WC, Nahvi A, Roth A, Collins JA, Breaker RR. Control of gene expression by a natural metabolite-responsive ribozyme. Nature 2004;428:281-6.

22. Frohlich KM, Weintraub SF, Bell JT, Todd GC, Väre VY, Schneider R, et al. Discovery of small-molecule antibiotics against a unique tRNA-mediated regulation of transcription in gram-positive bacteria. ChemMedChem 2019;14:758-69.

23. Sirajuddin M, Ali S, Badshah A. Drug-DNA interactions and their study by UV-Visible, fluorescence spectroscopies and cyclic voltametry. J Photochem Photobiol B 2013;124:1-19.

24. Jack K, Means J, Hines J. Characterizing riboswitch function: identification of $\mathrm{Mg}^{2+}$ binding site in T box antiterminator RNA. Biochem Biophys Res Commun 2008;370:306-10.

25. McPhie P, Brown P, Chen B, Dayie TK, Minton AP. Modulation of conformational equilibria in the S-Adenosylmethionine (SAM) II riboswitch by $\mathrm{SAM}, \mathrm{Mg} 2+$, and trimethylamine $\mathrm{N}$-oxide. Biochemistry 2016;55:5010-20.

Supplementary Material: The online version of this article offers supplementary material (https://doi.org/10.1515/tjb-2020-0168). 